Images in...

\title{
Unusual cause of cholangitis and diarrhoea after cholecystectomy
}

\author{
Venkata Lekharaju, Javaid lqbal, Omar Noorullah, Richard Sturgess \\ Gastroenterology Department, Aintree University Hospitals NHS Trust, Liverpool, Merseyside, UK
}

Correspondence to Dr Venkata Lekharaju, lekharajupawan@yahoo.com

\section{DESCRIPTION}

A 76-year-old Caucasian male was referred to us following his presentation with a 1 week history of fever with rigors and right upper quadrant pain. He had previously developed diarrhoea and weight loss following a cholecystectomy three months earlier, complicated by a hepatic duct injury which was repaired during the operation. Physical examination revealed fever and mild right hypochondrial tenderness. Laboratory investigations revealed total serum bilirubin of $61 \mathrm{umol} / 1$ (0-21umol/l); alanine aminotransferase of $105 \mathrm{u} / 1(11-55 \mathrm{u} / \mathrm{l})$; alkaline phosphatase $604 \mathrm{U} / 1$ (30-130 u/l). Blood cultures grew Gram negative bacilli and he was commenced on antibacterial therapy. A CT scan (figure 1) showed an inflammatory soft tissue lesion at the biliary hilum with bilobar intrahepatic ductal dilatation. Endoscopic retrograde cholangiopancreatography was attempted. The bile duct could not be cannulated and it was noted that there was no bile seen in the duodenum. Subsequently, the patient underwent a percutaneous transhepatic cholangiogram (figure 2). PTC has demonstrated a complete blockage at the hilum with free flow of contrast in the right colon suggestive of a biliary-colonic fistula (figure 3). He was referred for surgical correction and underwent a fistulectomy with limited colonic resection and a hepatico-jejunostomy. The patient remained well postprocedure with resolution of symptoms and weight gain during follow-up 3 months later. Biliary enteric fistulas can form anywhere between the extrahepatic biliary system and adjacent gastrointestinal tract. Fistulae occur as a complication following long-standing calculous biliary disease. In a recent review of cholecystocolonic fistulas, cholecystoduodenal fistulas accounted for over $70 \%$, while cholecystocolic fistulas constituted $8 \%$ to $26 \%{ }^{1}$ During laparoscopic cholecystectomy the major bile duct is injured between $0.15 \%$ and $0.45 \%$ of cases and is greater than during open procedure. ${ }^{2}$ Cholangitis and jaundice after cholecystectomy is most commonly due to retained common bile duct stones, but may also occur secondary to iatrogenic bile duct stricture. We believe in this case a biliary-colonic fistula developed on the background of an

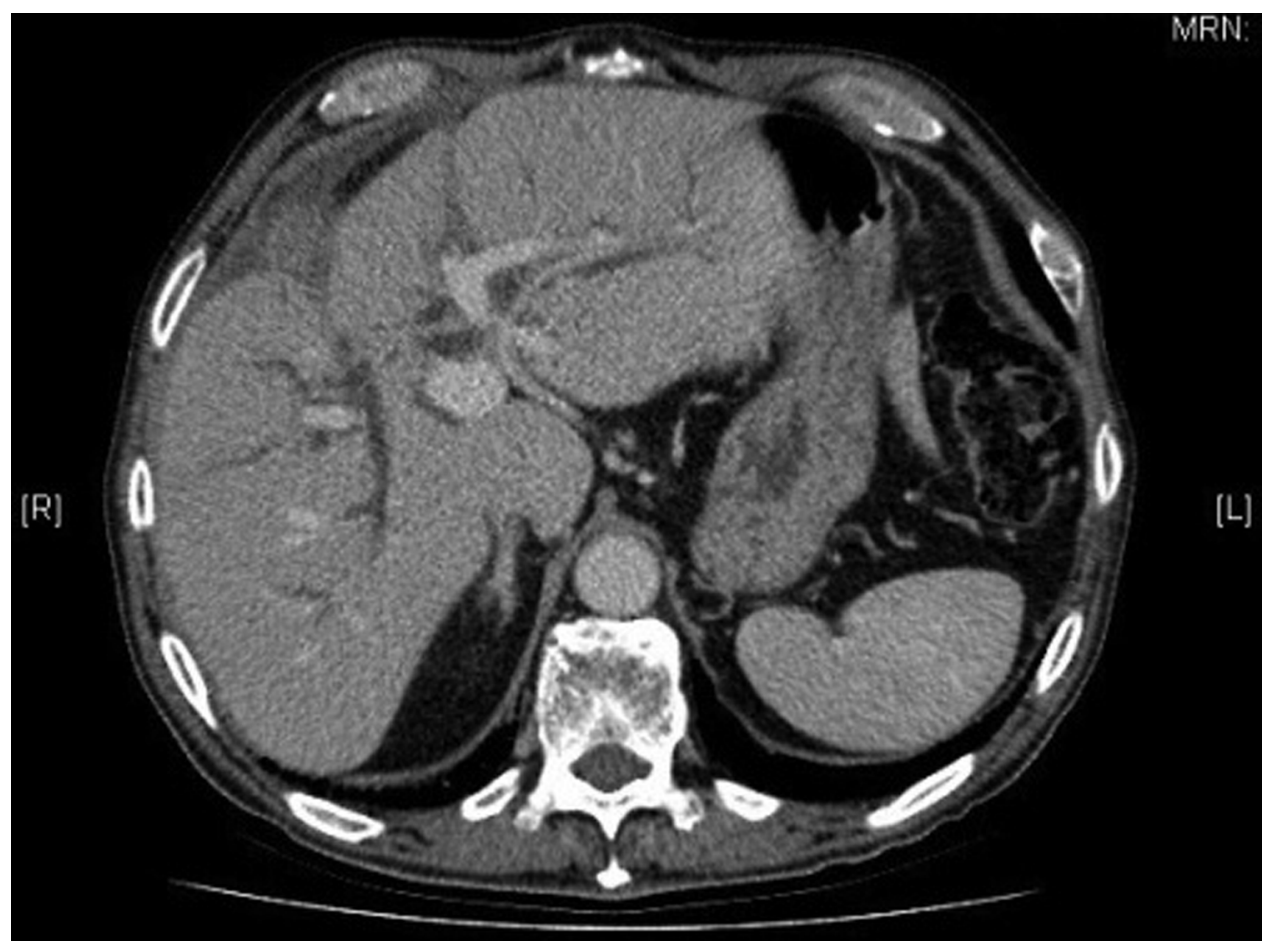

Figure 1 Axial CT image. 


\section{BMJ Case Reports}

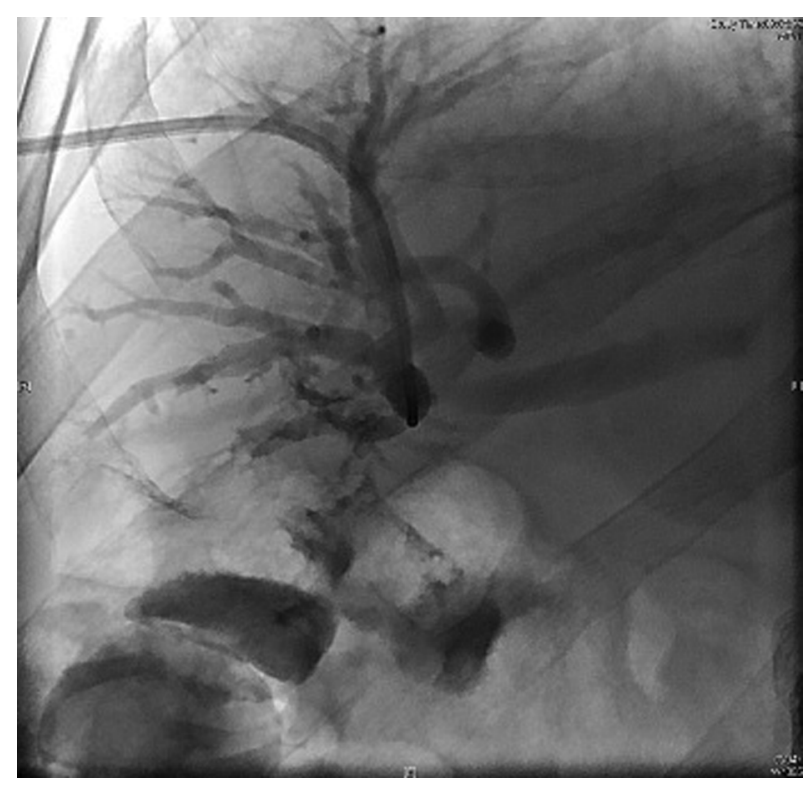

Figure 2 Image at percutaneous transhepatic cholangiogram.

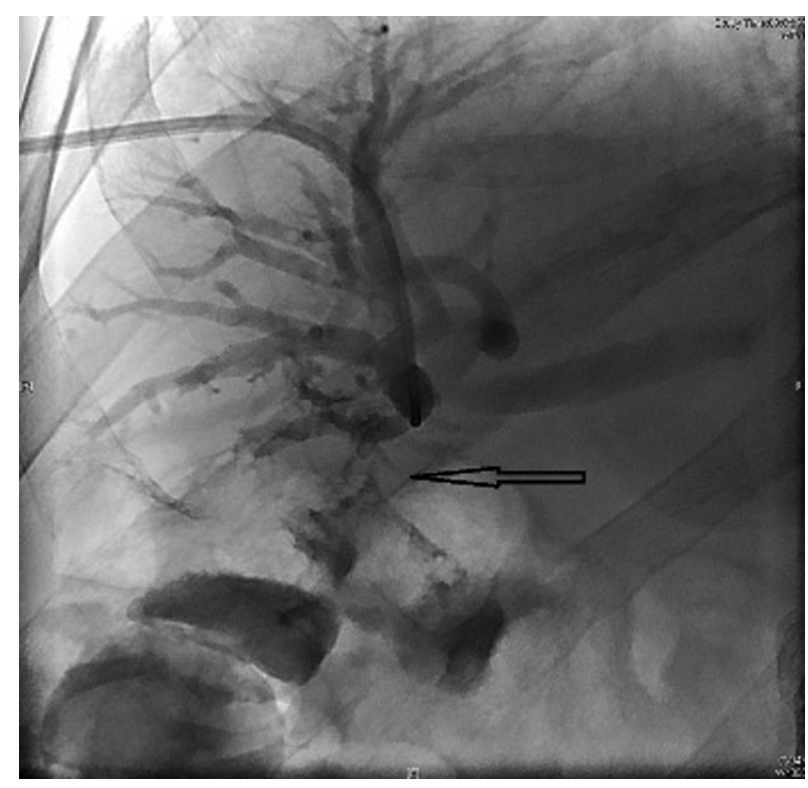

Figure 3 Percutaneous transhepatic cholangiogram demonstrating flow of contrast into the right colon (arrow) with complete obstruction at the biliary hilum.

E1 or E2 bile duct injury (Classification of bile duct injuries, Strasberg et $a^{\beta}$ ) with the formation of an internal biliary collection due to distal bile duct obstruction that eventually eroded into the colon. Although this is very unusual, it appears to be the only possibility, as there was no damage to the colon at the time of cholecystectomy. The presentation with cholangitis and absence of significant jaundice together with diarrhoea reflects the pathophysiology of this injury. Normally a biliary stricture resulting in marked intrahepatic duct dilatation would be associated with jaundice but in this case there was significant decompression into the colon preventing this from happening. However, the exposure of the colonic bacteria to the biliary system resulted in cholangitis and the drainage of bile into the colon caused diarrhoea, as bile salts enter the colon, bypassing the enterohepatic circulation resulting in the local concentration of bile acid in the colon to exceed 3 to $5 \mathrm{mmol} / \mathrm{l}$ and thereby inhibiting colonic fluid and electrolyte absorption and accelerate transit, working as a laxative. Biliary colonic fistula is rare, and the clinical presentation varies, patients may present with recurrent cholangitis, episodic jaundice and diarrhoea. We are aware of only a few cases of biliary colonic fistula resulting from iatrogenic injury during cholecystectomy. ${ }^{4}$ Clinical suspicion of fistulous communication should arise if there is evidence of biliary dilatation without significant jaundice and in the presence of diarrhoea and recurrent cholangitis. If timely repair is undertaken in experienced centres good results can be achieved.

Learning points

- Cholangitis and jaundice after cholecystectomy is most commonly due to retained common bile duct stones, but rarer causes like iatrogenic bile duct stricture and biliary enteric fistulas should always be considered.

- Clinical suspicion of fistulous communication should arise if there is evidence of biliary dilatation without significant jaundice and in the presence of diarrhoea and recurrent cholangitis.

Acknowledgements MrS Fenwick, Consultant Hepatobiliary Surgeon, Aintree University Hospitals NHS Foundation Trust, Liverpool, UK. Dr P Littler, Consultant Interventional Radiologist, Aintree University Hospitals NHS Foundation Trust, Liverpool, UK.

Competing interests None.

Patient consent Obtained.

\section{REFERENCES}

1. Costi R, Randone B, Violi V, et al. Cholecystocolonic fistula: facts and myths. A review of the 231 published cases. J Hepatobiliary Pancreat Surg 2009;16:8-18.

2. Dolan JP, Diggs BS, Sheppard BC, et al. Ten-year trend in the national volume of bile duct injuries requiring operative repair. Surg Endosc 2005;19:967-73.

3. Strasberg SM, Hertl M, Soper NJ. An analysis of the problem of biliary injury during laparoscopic cholecystectomy. J Am Coll Surg 1995;180:101-25.

4. Munene G, Graham JA, Holt RW, et al. Biliary-colonic fistula: a case report and literature review. Am Surg 2006;72:347-50. 


\section{BMJ Case Reports}

This pdf has been created automatically from the final edited text and images.

Copyright 2012 BMJ Publishing Group. All rights reserved. For permission to reuse any of this content visit http://group.bmj.com/group/rights-licensing/permissions.

BMJ Case Report Fellows may re-use this article for personal use and teaching without any further permission.

Please cite this article as follows (you will need to access the article online to obtain the date of publication).

Lekharaju V, Iqbal J, Noorullah O, Sturgess R. Unusual cause of cholangitis and diarrhoea after cholecystectomy. BMJ Case Reports 2012;

10.1136/bcr.12.2011.5340, Published XXX

Become a Fellow of BMJ Case Reports today and you can:

- Submit as many cases as you like

- Enjoy fast sympathetic peer review and rapid publication of accepted articles

- Access all the published articles

- Re-use any of the published material for personal use and teaching without further permission

For information on Institutional Fellowships contact consortiasales@bmjgroup.com

Visit casereports.bmj.com for more articles like this and to become a Fellow

Keep up to date with all published cases by signing up for an alert (all we need is your email address) http://casereports.bmj.com/cgi/alerts/etoc 